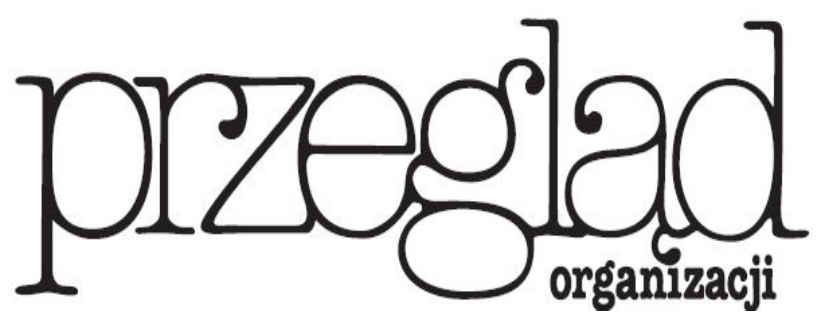

Miesięcznik TNOiK

Założył Karol Adamiecki w 1926 r.

\title{
POZIOM KOMPETENCJI STUDENTÓW W ZAKRESIE ZARZADZANIA PROJEKTAMI NA UNIWERSYTETACH I UCZELNIACH TECHNICZNYCH. PRZYPADEK PROGRAMU IPMA-STUDENT
}

https://doi.org/10.33141/po.2019.03.09

Joanna Rzempała, Tomasz Wiśniewski

Wprowadzenie

7 arządzanie projektami ma istotne znaczenie ekono$\angle$ miczne i gospodarcze. Projekty realizowane są we wszystkich sektorach i branżach (Turner i in., 2010; Winter i in., 2006, s. 638-649). Projekty stały się również ważne jako sposób organizacji pracy w większości organizacji (Bakker, 2010, s. 466-486) oraz stanowią jeden z kluczowych aktywności organizacyjnych (Winter i in., 2006 s. 638-649). Dlatego też ciągle wzrasta zaintereso-
Przegląd Organizacji, Nr 3 (950), 2019, ss. 58-67 www.przegladorganizacji.pl CTowarzystwo Naukowe Organizacji i Kierownictwa (TNOiK)

wanie zarządzaniem projektami. Pomimo tego tylko $29 \%$ projektów kończy się sukcesem (Standish Group, 2015). Złożoność, chaos i niepewność odgrywają w projektach i środowiskach projektowych coraz większą rolę, zarówno w badaniach, jak i w praktyce. Dlatego wzrasta potrzeba weryfikacji i aktualizacji rozumienia edukacji z zakresu zarządzania projektami, tak aby rozwijać kompetencje kierowników projektów, aby byli w stanie radzić sobie 
z rosnącym poziomem złożoności, chaosu i niepewności w środowiskach projektowych.

Celem artykułu jest prezentacja rezultatów badań przeprowadzonych metodą statystyczną wyników egzaminów certyfikacyjnych w zakresie zarządzania projektami (IPMA-Student). Celem głównym badań było określenie różnic kompetencyjnych $\mathrm{w}$ dwóch grupach studentów, tj. studentów uczelni technicznych i uniwersytetów (uniwersytety ekonomiczne lub wydziały ekonomiczne uniwersytetów, szkoły biznesu) oraz w kolejnym etapie grup studentów studiujących na kierunkach technicznych i ekonomiczno-zarządczych. Celem szczegółowym badań było określenie, w których obszarach kompetencji zarządzania projektami wyniki egzaminów poszczególnych grup różnią się znacząco oraz które elementy kompetencji są najlepiej rozwinięte wśród studentów poszczególnych grup.

\section{Znaczenie zarządzania projektami na rynku pracy}

W śród współczesnych wyzwań w dziedzinie zarządzania projektami i wynikających $\mathrm{z}$ nich potrzeb edukacyjnych szczególną uwagę zwraca się na (Gemünden, Schoper, 2014 za Trocki, Bukłaha, 2015):

- dalsze zwiększanie roli projektów w społeczeństwie,

- rosnący zakres złożonych projektów,

- coraz większy udział i znaczenie projektów międzynarodowych,

- konieczność rozwoju badań naukowych w zakresie zarządzania projektami,

- eksponowanie charakteru biznesowego projektów,

- potrzebę zorientowania projektowego w zarządzaniu organizacjami,

- zwrócenie uwagi najwyższego kierownictwa na problemy zarządzania projektami,

- współpracę z interesariuszami jako zasadniczy warunek sukcesu projektów,

- docenienie roli kobiet w zarządzaniu projektami.

W celu sprostania powyższym wyzwaniom zakłada się dalszą profesjonalizację zarządzania projektami, co oznacza konieczność szerszego niż dotychczas udziału problematyki zarządzania projektami tak w światowej, jak i polskiej nauce oraz edukacji (Trocki, Bukłaha, 2015; Łapuńka, Pisz, 2016, s. 141-154).

Pracodawcy i społeczeństwa poszukują absolwentów kompetentnych i gotowych do pracy. Podczas gdy zapotrzebowanie na wysoko wykwalifikowanych pracowników stale rośnie, rozbieżność między kompetencjami absolwentów a kwalifikacjami poszukiwanymi przez pracodawców nadal stanowi poważny problem $\mathrm{w}$ różnych krajach (Al-Emranab $\mathrm{i}$ in., 2016, s. 93-102).

W Polsce w roku 2017 przeprowadzone zostały badania w ramach II edycji Bilansu Kapitału Ludzkiego, które potwierdziły wyniki badań z lat wcześniejszych. Podobnie jak w latach 2010-2014, pracodawcy najczęściej wskazywali na (PARP, 2016):

- kompetencje zawodowe, odnoszące się do specyficznych umiejętności niezbędnych do wykonywania zadań na określonym stanowisku,
- kompetencje samoorganizacyjne, a szczególnie na staranność, skrupulatność oraz odpowiedzialność,

- kompetencje interpersonalne ze szczególnym naciskiem na łatwość nawiązywania kontaktów, pracę w grupie oraz komunikatywność.

Jak wynika z Raportu Niedobór talentów 2018 w Polsce, największe trudności $\mathrm{w}$ pozyskiwaniu pracowników zgłaszają duże firmy (zatrudniające powyżej 250 osób). Nieco mniejsze trudności deklarują przedstawiciele średnich (50-250 pracowników), małych (10-49) i mikroprzedsiębiorstw (mniej niż 10). Większość z dziesięciu najbardziej pożądanych zawodów wymaga dodatkowych szkoleń, jednak nie każdy z nich wymaga posiadania dyplomu uniwersyteckiego. Stanowiska dla średnio wykwalifikowanych pracowników jak między innymi te wymienione powyżej stanowią $40 \%$ wszystkich miejsc pracy w OECD, a zapotrzebowanie na nie wciąż rośnie. W erze cyfryzacji zatrudnienie nie zawsze wymagać będzie wykształcenia wyższego, jednak będzie w dużym stopniu opierało się na ciągłym rozwijaniu umiejętności (Manpower Group, 2018). Warto zauważyć, że połączenie kompetencji zawodowych technicznych (usytuowane na trzecim miejscu w Raporcie Niedobór talentów) i kompetencji prowadzenia projektów, może dać zdecydowaną przewagę na konkurencyjnym rynku pracy.

\section{Kompetencje zarządzania projektami a model kompetencyjny IPMA-Student}

W śród czynników determinujących sukces projektu, takich jak zidentyfikowany cel, planowanie, są również kierownicy projektów i zespoły projektowe oraz ich kompetencje (Wirkus, Tubielewicz, 2018, s. 165-178), przywództwo; kompetencje społeczne i inteligencji emocjonalnej; komunikacji; umiejętności w zakresie organizacji polityki; oraz znaczenie wizji, wartości (Dainty i in., 2005).

Kierownicy projektów oprócz kompetencji technicznych potrzebują również kompetencji społecznych, takich jak: kompetencji do tworzenia zespołów, które mogą pracować dynamicznie i twórczo w kierunku realizacji celów w zmieniającym się otoczeniu w poprzek organizacyjnych linii funkcjonalnych (Thomas, Mengel, 2008, s. 304-315). A. Dainty dodał do wymaganych kompetencji kierownika projektów kompetencje orientacji na klienta, elastyczności i samokontroli (Keegan, Den Hertogg, 2004, s. 609-617). V. Dulewicz i M. Higgs (2003) wskazali, że również kompetencje emocjonalne kierowników są istotne, według przeprowadzonych badań, aż $36 \%$ mają one wpływ na przywództwo w projekcie.

Wciąguostatnichdziesięcioleciopracowanowielestandardów dotyczących zarządzania projektami, które przyczyniły się do zwiększenia stopnia profesjonalizmu tego obszaru. International Project Management Association (IPMA), które reprezentuje lokalne stowarzyszenia profesjonalne z różnych krajów Europy, Azji i Afryki’ opracowała własne standardy i certyfikację.

W 1996 roku Australijski Instytut Zarządzania Projektami (AIPM) opublikował krajowy standard kompetencji dla projektu, który został przyjęty przez rząd jako krajowa rama kwalifikacji. W Anglii stworzono również standardy 
kompetencji wokół kontroli projektu i zarządzania projektem (Thomas, Mengel, 2008, s. 304-315).

Przedstawione systemy certyfikacji kompetencji kierowników i członków zespołów projektowych potwierdzają nabyte kwalifikacje i umiejętności praktyków biznesowych. Biorąc jednak pod uwagę wyniki badań w zakresie ciągle istniejącej luki pomiędzy potrzebami rynku pracy a kompetencjami osób jej poszukujących, istotne wydaje się pytanie o system kształcenia i kompetencje absolwentów uczelni wyższych wchodzących każdego roku na rynek pracy. Czy system edukacji akademickiej oraz studenci zauważają potrzebę rozwijania kompetencji zarządzania projektami?

Odpowiedzią na to pytanie jest stale wrastająca liczba specjalności i przedmiotów obejmujących zagadnienia związane z zarządzaniem projektami. W ostatnich dwóch latach powstały również w Polsce pierwsze kierunki zarządzania projektami na uczelniach wyższych, m.in. w Szkole Głównej Handlowej w Warszawie i na Wydziale Organizacji i Zarządzania Politechniki Śląskiej.

Świadomość takiej potrzeby wśród uczelni i przedsiębiorców doprowadziła również do wypracowania uniwersalnego i przejrzystego modelu wymagań kompetencyjnych zarządzania projektami. Uwzględnia on najlepsze praktyki i potrzeby rynku pracy, daje podstawy uczelniom do dostosowywania i rozwoju swoich programów nauczania (system akredytacji uczelni IPMA-Student). Oparty na nim system certyfikacji IPMA-Student zwiększa szanse studentów na rynku pracy (certyfikat IPMA-Student ${ }^{1}$ ), a dla przedsiębiorców stanowi potwierdzenie kompetencji kandydata.

Model ten opiera się na Wytycznych Kompetencji IPMA (Dałkowski i in., 2009), gdzie wyróżniono trzy obszary kompetencji:
Obszar kompetencji technicznych obejmuje podstawowe elementy kompetencji w zarządzaniu projektami, stanowiące sedno profesjonalnego zarządzania projektami, jego elementy określa się niekiedy mianem twardych.

Obszar kompetencji behawioralnych obejmuje osobowościowe elementy kompetencji w zarządzaniu projektami, w szczególności postawy i zachowania kierownika projektu, jego elementy określa się niekiedy mianem miękkich.

Obszar kompetencji kontekstowych obejmuje elementy odnoszące się do kontekstu projektu, w szczególności strategii organizacji, relacji pomiędzy projektem a działalnością operacyjną, relacji kierownika projektu i zespołu zarządzającego projektem z kierownictwem liniowym i kierownictwem biznesowym organizacji oraz do funkcjonowania w ramach organizacji zorientowanej na projekty, programy i portfele.

Każdy element kompetencji w poszczególnych obszarach definiowany jest przez nazwę, opis zawartości, listę zagadnień objętych tematem, listę możliwych działań, kluczowe kompetencje wymagane na każdym $\mathrm{z}$ czterech poziomów certyfikacji IPMA, kluczowe terminy i kluczowe relacje $\mathrm{z}$ innymi elementami kompetencji.

Program funkcjonuje od 2014 roku, został wdrożony na 23 wydziałach uczelni w Polsce, $10 \mathrm{z}$ nich realizuje egzaminy certyfikacyjne IPMA-Student, są już zatem podstawy do weryfikacji efektywności kształcenia studentów przy zastosowaniu modelu.

Warto podkreślić, że wśród uczelni, które uzyskały akredytację IPMA-Student, oprócz tych, które tylko potwierdziły zgodność swoich programów nauczania $\mathrm{z}$ wymaganiami IPMA-Student, znalazły się i takie, które uruchomily nowe programy w oparciu o efekty kształcenia IPMA-Student.

Rozwój programu certyfikacji IPMA-Student opiera się na okresowej analizie wymagań dotyczących stanowisk i praktyk zarządzania projektami oraz wymagań i uwarunkowań szkol-

Tabela 1. Elementy kompetencji wg modelu IPMA-Student

\begin{tabular}{|c|c|c|}
\hline $\begin{array}{l}\text { Elementy kompetencji } \\
\text { technicznych }\end{array}$ & $\begin{array}{l}\text { Elementy kompetencji } \\
\text { behawioralnych }\end{array}$ & $\begin{array}{l}\text { Elementy kompetencji } \\
\text { kontekstowych }\end{array}$ \\
\hline $\begin{array}{l}\text { 1.01 Sukces zarządzania projektem } \\
\text { 1.02 Interesariusze } \\
\text { 1.03 Wymagania i cele projektu } \\
\text { 1.04 Ryzyko: zagrożenia i szanse } \\
\text { 1.05 Jakość } \\
\text { 1.06 Organizacja projektu } \\
\text { 1.07 Praca zespołowa } \\
\text { 1.08 Rozwiązywanie problemów } \\
\text { 1.09 Struktury projektu } \\
\text { 1.10 Zakres i produkty cząstkowe } \\
1.11 \text { Czas i etapy (fazy) projektu } \\
1.12 \text { Zasoby } \\
1.13 \text { Koszty i zasoby finansowe } \\
1.15 \text { Zmiany } \\
1.16 \text { Kontrola i raporty } \\
1.18 \text { Komunikacja } \\
1.19 \text { Rozpoczynanie } \\
1.20 \text { Zamykanie }\end{array}$ & $\begin{array}{l}\text { 2.01 Przywództwo } \\
\text { 2.02 Zaangażowanie i motywacja } \\
\text { 2.04 Asertywność } \\
\text { 2.07 Kreatywność } \\
\text { 2.08 Zorientowanie na wyniki } \\
\text { 2.09 Sprawność } \\
\text { 2.12 Konflikty i kryzysy } \\
\text { 2.13 Wiarygodność } \\
\text { 2.14 Docenianie wartości } \\
\text { 2.15 Etyka }\end{array}$ & $\begin{array}{l}\text { 3.01 Orientacja na projekty } \\
\text { 3.05 Stałe struktury organizacji } \\
\text { 3.08 Zarządzanie zasobami ludzkimi }\end{array}$ \\
\hline
\end{tabular}

Źródto: opracowanie na podstawie materiatów IPMA 
nictwa wyższego. Analiza przeprowadzana jest przez Komitet Programowy ds. Certyfikacji przynajmniej raz na pięć lat.

\section{Badanie kompetencji studentów w zakresie zarządzania projektami}

\section{Metoda i próba badawcza}

W badaniu wykorzystano metodę statystyczną oraz metodę indywidualnych przypadków. Dane pochodziły z portalu IPMA-Student z wyników egzaminu w wersji elektronicznej. Do opracowania wyników analizy użyto oprogramowania MS Excel 2013. Wykonano podstawowe analizy statystyczne. Dodatkowo porównano dwie badane grupy ze względu na wynik egzaminu IPMA-Student. Wykorzystano do tego jednoczynnikową analizę wariancji.

Próba badawcza obejmuje studentów 10 akredytowanych uczelni ${ }^{2}$, które przeprowadziły egzaminy certyfikacyjne IPMA-Student w wersji elektronicznej (część uczelni korzysta $z$ wersji papierowej). Są to uczelnie o różnym profilu kształcenia, w grupie tej są zarówno uniwersytety, szkoły biznesu, jak i uczelnie techniczne. Studenci objęci badaniem studiują na różnych kierunkach, jak też specjalnościach, tzn. zarówno związanych z zarządzaniem, jak i kierunkami technicznymi, na I lub II stopniu studiów stacjonarnych (łącznie 291 osób).

Dane dotyczące wyników egzaminów studentów pochodzą z elektronicznej platformy egzaminacyjnej - portalu IPMA-Student. Do opracowania wyników wykorzystano oprogramowanie MS Excel 2013. W ramach badania:

- wykonano podstawowe analizy statystyczne,

- porównano badane grupy ze względu na wynik egzaminu IPMA-Student,

- zastosowano jednoczynnikową analizę wariancji.

\section{Analiza wyników certyfikacji studentów}

Analiza statystyczna wyników e-egzaminu IPMA-Student przedstawiona została w tabeli 2. Do badania wykorzystano wyniki z egzaminów przeprowadzonych w formie elektronicznej - 291 egzaminów. Zarówno średni wynik, jak i mediana wyniku uzyskiwanego przez studentów wynosi $61 \%$. Odchylenie standardowe wynosi $9 \%$, co świadczy o stosunkowo niewielkim zróżnicowaniu wyników (większość koncentruje się wokół średniej).

Rozkład wyników uzyskanych na e-egzaminie IPMA-Student przedstawia rysunek 1. Minimalny wynik w skali 100 wynosi 36, maksymalny 81 (rys. 1). Rozkład wyników układa się w przybliżeniu zgodnie z rozkładem normalnym. Mediana i wartość średnia są takie same, co świadczy o symetryczności rozkładu.

Badając mocne i słabe obszary wiedzy studentów, analizowano wyniki uzyskane na e-egzaminie w poszczególnych obszarach kompetencji IPMA (tab. 3), a następnie w poszczególnych elementach kompetencji (tab. 4-6).

Wyniki w obszarze kompetencji behawioralnych są istotne statystycznie lepsze niż w pozostałych obszarach $\left(\right.$ tab. 3) ${ }^{3}$. Najsłabiej rozwinięte są kompetencje kontekstowe, co wydaje się zrozumiałe, biorąc pod uwagę mniejsze doświadczenie praktyczne studentów.
Tabela 2. Wyniki egzaminów IPMA-Student

\begin{tabular}{|l|c|}
\hline \multicolumn{1}{|c|}{ Wyszczególnienie } & e-egzamin IPMA-Student \\
\hline Łączna liczba podejść & 291 \\
\hline $\begin{array}{l}\text { Srednia ocena wszystkich } \\
\text { podejść }\end{array}$ & $61 \%$ \\
\hline Mediana & $61 \%$ \\
\hline Odchylenie standardowe & $9 \%$ \\
\hline $\begin{array}{l}\text { Współczynnik asymetrii } \\
\text { (Skośność) }\end{array}$ & $-0,14$ \\
\hline Kurtoza & $-0,3$ \\
\hline $\begin{array}{l}\text { Współczynnik spójności } \\
\text { wewnętrznej }\end{array}$ & $77 \%$ \\
\hline
\end{tabular}

Źródło: opracowanie własne

Tabela 3. Wskaźnik poprawnych odpowiedzi na pytania w poszczególnych obszarach kompetencji IPMA

\begin{tabular}{|l|c|}
\hline \multicolumn{1}{|c|}{$\begin{array}{c}\text { Obszar kompetencji } \\
\text { IPMA-Student }\end{array}$} & $\begin{array}{c}\text { Średni procent } \\
\text { poprawnych odpowiedzi }\end{array}$ \\
\hline 1.0 Techniczne & $58,63 \%$ \\
\hline 2.0 Behawioralne & $\mathbf{7 6 , 1 4 \%}$ \\
\hline 3.0 Kontekstowe & $55,95 \%$ \\
\hline
\end{tabular}

Źródto: opracowanie wtasne

Analizując wyniki w zakresie poszczególnych elementów kompetencji, można wnioskować, iż:

- w ramach kompetencji technicznych najwięcej poprawnych odpowiedzi udzielono na pytania dotyczące rozwiązywania problemów i komunikacji, najmniej dotyczących ryzyka projektu oraz jakości i faz zarządzania projektami (tab. 4),

- w obszarze kompetencji behawioralnych najlepsze wyniki studenci uzyskali w zakresie pytań dotyczących zaangażowania i motywacji oraz asertywności, natomiast najsłabsze wyniki dotyczyły przywództwa i zarządzania konfliktem (tab. 5),

- najlepiej rozwinięte elementy kompetencji kontekstowych to zarządzanie zasobami ludzkimi, najsłabiej dotyczące orientacji na projekty (tab. 6).

Oceniając statystyczną wiarygodność wyników w poszczególnych obszarach kompetencji, należy uwzględnić, że w zestawie egzaminacyjnym złożonym ze 100 pytań, zgodnie $\mathrm{z}$ wymaganiami kompetencyjnymi IPMA-Student, 70 pytań dotyczy kompetencji technicznych, 15 pytań kompetencji behawioralnych, 15 pytań kompetencji kontekstowych.

Analogiczne analizy są prowadzone dla poszczególnych akredytowanych uczelni. Ich wyniki mogą być przesłanką dla poprawy jakości kształcenia w obszarach czy wręcz konkretnych elementach kompetencji, w których wyniki są niesatysfakcjonujące.

W ramach badania wykonano także szczegółowe analizy porównawcze wyniku końcowego egzaminu IPMA-Student dla dwóch grup: grupa I - studenci z uniwersytetów 
(uniwersytety ekonomiczne lub wydziały ekonomiczne uniwersytetów, szkoły biznesu) - 111 osób oraz grupa II - studenci uczelni technicznych (politechniki) - 183 osoby.

Porównanie wykonano, stosując analizę wariancji (ang. ANOVA - Analysis of Variance), która porównuje wyniki poszczególnych grup ze względu na ocenę wyniku egzaminu. Średnie wyniki obu analizowanych grup są bardzo zbliżone, dla studentów z grupy uniwersytetów: 60,73, dla uczelni technicznych 60,86. Wyniki są pokazane $\mathrm{w}$ tabeli 7 . Z tabeli można odczytać, że wartość $F$ (Fishera) jest zdecydowanie mniejsza niż wartość teoretyczna testu $\mathrm{F}$ przy jednocześnie wysokim poziomie $p$-wartość (zazwyczaj przyjmuje się poniżej $0,05)$. Wynika $z$ tego, że dwie analizowane grupy studentów uniwersytetów oraz uczelni technicznych nie różnią się w sposób statycznie istotny ze względu na wynik egzaminu.

Kolejna wykonana analiza zawiera porównanie ocen poszczególnych obszarów kompetencji dla dwóch analizowanych grup studentów. Wyniki porównania zawarte są w tabeli 8. Można zauważyć, iż różnice dla poszczególnych obszarów kompetencji nie są znaczące, co więcej, dla wielu obszarów nie przekraczają kilku punktów procentowych. Co potwierdza wcześniejszy wniosek $\mathrm{z}$ tabeli 7 o braku statystycznej różnicy pomiędzy wynikami w tych grupach. W tabeli 8 pokazano, że jedynie w niektórych obszarach kompetencji analizowane grupy (studenci uniwersytety oraz uczelni technicznych) różnią się w sposób umiarkowanie istotny:

- 1.08 Rozwiązywanie problemów

- 1.12 Zasoby

-2.08 Zorientowanie na wyniki

- 2.12 Konflikty i kryzysy

Ze względu na fakt, iż w badaniach uczestniczyły wydziały na uczelniach technicznych, na których studenci studiowali na kierunkach związanych z zarządzaniem lub typowo technicznych, wykonano analizę dla studentów kierunków ekonomicznych i zarządczych (zarówno uniwersytety i wydziały zarządzania uczelni technicznych) - 230 osób oraz studentów kierunków stricte technicznych (tylko uczelnie techniczne) - 63 osoby.

Pierwsze porównanie dotyczy ogólnego wyniku egzaminu IPMA-Student. Średnie wyniki dla obu grup także są bardzo zbliżone: 60,91 dla studentów kierunków ekonomicznych i zarządczych oraz 60,43 dla studentów kierunków technicznych. Jako statystyczne potwierdzenie braku istotnych różnic w obu grupach wykonano analizę ANOVA (tab. 9). Z tabeli można odczytać relatywnie małą wartość statystyki $\mathrm{F}$ w porównaniu do teoretycznej wartości testu F, przy wysokiej p-wartości - oznacza to brak statystycznie istotnej różnicy pomiędzy badanymi grupami.

Dalsza analiza zawiera porównanie ocen poszczególnych obszarów kompetencji dla dwóch analizowanych grup studentów kierunków ekonomicznych i zarządzania oraz technicznych. Wyniki porównania zawarte są w tabeli 10. Można zauważyć, iż różnice dla poszczególnych obszarów kompetencji również nie różnią się $\mathrm{w}$ istotny sposób (tak jak w poprzednim porównaniu - tab. 8). Potwierdza to wniosek z Tabeli 9 o braku statystycznej różnicy pomiędzy wynikami w tych grupach. Tabela 10 wskazuje, że jedynie w niektórych elementach kompetencji analizowane grupy (studenci kierunków ekonomicznych i zarządzania oraz technicznych) różnią się w sposób umiarkowanie istotny:

- 1.05 Jakość

-1.08 Rozwiązywanie problemów

- 2.07 Kreatywność

- 2.15 Etyka

\section{Możliwe determinanty wyników egzaminów}

Egzaminy IPMA-Student (IS) są realizowane na akredytowanych wydziałach uczelni dla studentów, którzy zrealizowali ścieżkę akredytowanych przedmiotów w liczbie co najmniej 60 godzin na studiach dziennych i 30 na studiach zaocznych. Studenci przystępują do egzaminów fakultatywnie. Można więc wnioskować, iż są to jednostki szczególnie zainteresowane zarządzaniem projektami, które łączą z tą dziedziną swoją przyszłość.

Akredytacja uczelni jest potwierdzeniem, iż student ma możliwość zapoznania się z treściami dydaktycznymi związanymi z zarządzaniem projektami, zgodnymi w wymogami modelu IPMA-Student. Komisja akredytacyjna nie weryfikuje jakości kształcenia, a jedynie treści programu.

W ramach badania przeanalizowano część odpowiedzi ankiety satysfakcji studentów, wypełnianej po napisaniu egzaminu. Analizowano głównie odpowiedzi na wybrane pytania dotyczące m.in. zgodności tematyki pytań i terminologii stosowanej na egzaminie IS $\mathrm{w}$ porównaniu $\mathrm{z}$ tą stosowaną $\mathrm{w}$ ramach procesu dydaktycznego na uczelni. Wyniki ankiety przedstawiono $\mathrm{w}$ analizie porównawczej dla dwóch analizowanych grup

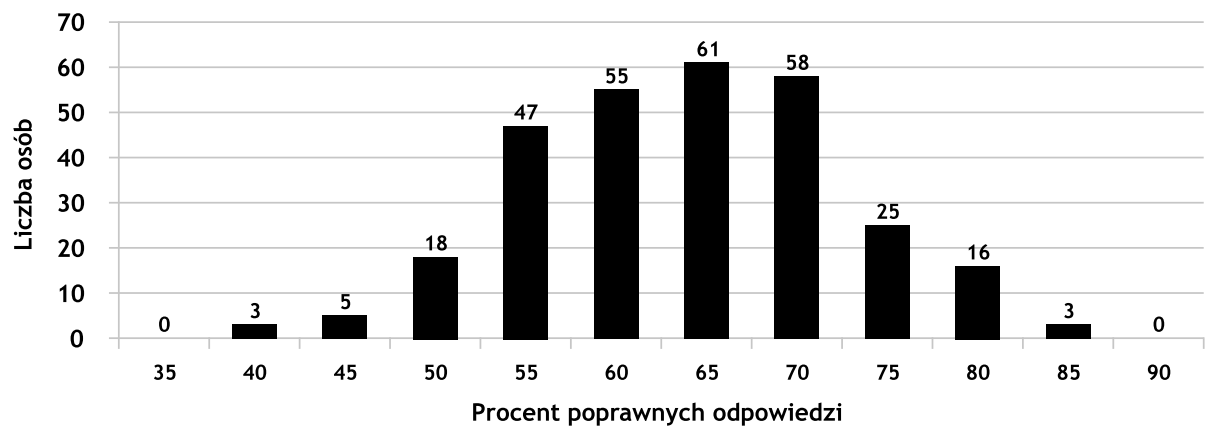

Rys. 1. Rozkład wyników e-egzaminu IPMA-Student

Źródło: opracowanie własne 
Tabela 4. Wynik w obszarze kompetencji technicznych na egzaminie IPMA-Student

\begin{tabular}{|l|c|}
\hline \multicolumn{1}{|c|}{ Elementy kompetencji } & $\begin{array}{c}\text { Średni procent } \\
\text { poprawnych odpowiedzi }\end{array}$ \\
\hline $\begin{array}{l}1.01 \text { Sukces zarządzania } \\
\text { projektem }\end{array}$ & $68,69 \%$ \\
\hline 1.02 Interesariusze & $70,69 \%$ \\
\hline 1.03 Wymagania i cele projektu & $69,49 \%$ \\
\hline 1.04 Ryzyko: zagrożenia i szanse & $33,85 \%$ \\
\hline 1.05 Jakość & $44,92 \%$ \\
\hline 1.06 Organizacja projektu & $66,97 \%$ \\
\hline 1.07 Praca zespołowa & $56,90 \%$ \\
\hline 1.08 Rozwiązywanie problemów & $80,52 \%$ \\
\hline 1.09 Struktury projektu & $52,41 \%$ \\
\hline 1.10 Zakres i produkty & $48,14 \%$ \\
\hline cząstkowe & $45,17 \%$ \\
\hline 1.11 Czas i etapy (fazy) projektu & $63,91 \%$ \\
\hline 1.12 Zasoby & $67,64 \%$ \\
\hline 1.13 Koszty i zasoby finansowe & $60,34 \%$ \\
\hline 1.15 Zmiany & $71,24 \%$ \\
\hline 1.16 Kontrola i raporty & $\mathbf{8 3 , 3 3 \%}$ \\
\hline 1.18 Komunikacja & \\
\hline
\end{tabular}

Źródto: opracowanie własne
Tabela 5. Wyniki w obszarze kompetencji behawioralnych na egzaminie IPMA - Student

\begin{tabular}{|l|c|}
\hline \multicolumn{1}{|c|}{ Elementy kompetencji } & $\begin{array}{c}\text { Średni procent } \\
\text { poprawnych odpowiedzi }\end{array}$ \\
\hline 2.01 Przywództwo & $57,93 \%$ \\
\hline 2.02 Zaangażowanie i motywacja & $\mathbf{9 7 , 7 6 \%}$ \\
\hline 2.04 Asertywność & $94,48 \%$ \\
\hline 2.07 Kreatywność & $72,64 \%$ \\
\hline 2.08 Zorientowanie na wyniki & $91,38 \%$ \\
\hline 2.12 Konflikty i kryzysy & $53,28 \%$ \\
\hline 2.13 Wiarygodność & $90,69 \%$ \\
\hline 2.14 Docenianie wartości & $81,03 \%$ \\
\hline 2.15 Etyka & $90,69 \%$ \\
\hline
\end{tabular}

Źródło: opracowanie własne

Tabela 6. Wyniki w obszarze kompetencji kontekstowych na egzaminie IPMA-Student

\begin{tabular}{|l|c|}
\hline \multicolumn{1}{|c|}{ Elementy kompetencji } & $\begin{array}{c}\text { Średni procent } \\
\text { poprawnych odpowiedzi }\end{array}$ \\
\hline 3.01 Orientacja na projekty & $49,92 \%$ \\
\hline 3.05 Stałe struktury organizacji & $52,13 \%$ \\
\hline 3.08 Zarządzanie zasobami ludzkimi & $\mathbf{6 5 , 3 8 \%}$ \\
\hline
\end{tabular}

Źródło: opracowanie własne

Tabela 7. Porównanie wyników ogólnych egzaminu dla studentów - perspektywa typów uczelni - analiza wariancji (ANOVA)

\begin{tabular}{|c|c|c|c|c|c|c|}
\hline \multicolumn{2}{|c|}{ PODSUMOWANIE } & \multirow[b]{2}{*}{$\begin{array}{c}\text { Suma } \\
\text { uzyskanych } \\
\text { punktów }\end{array}$} & \multirow[b]{2}{*}{$\begin{array}{l}\text { Średnia } \\
\text { punktów }\end{array}$} & \multirow[b]{2}{*}{$\begin{array}{c}\text { Wariancja } \\
\text { punktów }\end{array}$} & & \\
\hline Grupy & $\begin{array}{c}\text { Liczba } \\
\text { egzaminów }\end{array}$ & & & & & \\
\hline Uniwersytety & 111 & 6741 & 60,72973 & 64,56265 & & \\
\hline $\begin{array}{l}\text { Uczelnie } \\
\text { techniczne }\end{array}$ & 183 & 11138 & 60,86339 & 83,17354 & & \\
\hline \multicolumn{2}{|c|}{ ANOVA } & & & & & \\
\hline $\begin{array}{c}\text { Źródło } \\
\text { wariancji }\end{array}$ & SS & df & MS & $\mathbf{F}$ & Wartość-p & Test F \\
\hline $\begin{array}{l}\text { Pomiędzy } \\
\text { grupami }\end{array}$ & 1,234293 & 1 & 1,234293 & 0,016206 & 0,898788 & 3,873502 \\
\hline W obrębie grup & 22239,48 & 292 & 76,16259 & & & \\
\hline Razem & 22240,71 & 293 & & & & \\
\hline
\end{tabular}

Źródto: opracowanie wtasne

studentów: z uniwersytetów i szkół biznesu oraz z uczelni technicznych.

Wyniki ankietowe wskazują, iż treści programów kształcenia są zgodne z tematyką egzaminu w prawie $70 \%$ uniwersytetów i 50\% uczelni technicznych. Niezgodność występuje w 3\% uniwersytetów i 7\% uczelni technicznych (rys. 2).

Studentów zapytano również o zgodność terminologii zarządzania projektami używanej podczas egzaminu i zajęć dydaktycznych. Obszar ten jest często podnoszony jako utrudniający komunikację w zespole projektowym oraz z interesariuszami projektów. Wyniki ankiety wskazują, iż w obu grupach wyniki są podobne i wskazują, iż niezgodność terminów zauważa jedynie 3\% studentów z Uniwersytetów i 5\% Uczelni technicznych (rys. 3).
Wyniki ankiet dotyczących satysfakcji studentów są udostępniane akredytowanym uczelniom, co daje im wiedzę na temat ewentualnych zastrzeżeń, problemów i potrzeb dydaktycznych, na których należy się skoncentrować w celu poprawy jakości nauczania studentów.

\section{Podsumowanie}

D rzeprowadzone badania na podstawie wyników certyfikacji studentów polskich uczelni w ramach Programu IPMA-Student wskazują, iż:

- studenci akredytowanych uczelni najwyższe wyniki osiągają w zakresie kompetencji behawioralnych, 
Tabela 8. Porównanie wyników egzaminów w poszczególnych obszarach kompetencji z perspektywy typów uczelni

\begin{tabular}{|c|c|c|c|}
\hline & Uniwersytety & Uczelnie techniczne & Różnica \\
\hline Obszar kompetencji technicznych & $58,43 \%$ & $58,75 \%$ & $-0,32 \%$ \\
\hline 1.01 Sukces zarządzania projektem & $67,59 \%$ & $69,34 \%$ & $-1,75 \%$ \\
\hline 1.02 Interesariusze & $72,53 \%$ & $69,60 \%$ & $2,93 \%$ \\
\hline 1.03 Wymagania i cele projektu & $70,37 \%$ & $68,96 \%$ & $1,42 \%$ \\
\hline 1.04 Ryzyko: zagrożenia i szanse & $32,41 \%$ & $34,71 \%$ & $-2,30 \%$ \\
\hline 1.05 Jakość & $41,44 \%$ & $46,98 \%$ & $-5,54 \%$ \\
\hline 1.06 Organizacja projektu & $67,59 \%$ & $66,59 \%$ & $1,00 \%$ \\
\hline 1.07 Praca zespołowa & $59,82 \%$ & $55,17 \%$ & $4,65 \%$ \\
\hline 1.08 Rozwiązywanie problemów & $90,28 \%$ & $74,73 \%$ & $15,56 \%$ \\
\hline 1.09 Struktury projektu & $54,32 \%$ & $51,28 \%$ & $3,04 \%$ \\
\hline 1.10 Zakres i produkty cząstkowe & $46,48 \%$ & $49,12 \%$ & $-2,64 \%$ \\
\hline 1.11 Czas i etapy (fazy) projektu & $46,30 \%$ & $44,51 \%$ & $1,79 \%$ \\
\hline 1.12 Zasoby & $58,03 \%$ & $67,40 \%$ & $-9,37 \%$ \\
\hline 1.13 Koszty i zasoby finansowe & $66,67 \%$ & $68,21 \%$ & $-1,54 \%$ \\
\hline 1.15 Zmiany & $61,11 \%$ & $59,89 \%$ & $1,22 \%$ \\
\hline 1.16 Kontrola i raporty & $70,19 \%$ & $71,87 \%$ & $-1,68 \%$ \\
\hline 1.18 Komunikacja & $80,86 \%$ & $84,80 \%$ & $-3,94 \%$ \\
\hline Obszar kompetencji behawioralnych & $75,49 \%$ & $76,52 \%$ & $-1,03 \%$ \\
\hline 2.01 Przywództwo & $57,72 \%$ & $58,06 \%$ & $-0,34 \%$ \\
\hline 2.02 Zaangażowanie i motywacja & $97,69 \%$ & $97,80 \%$ & $-0,11 \%$ \\
\hline 2.04 Asertywność & $93,52 \%$ & $95,05 \%$ & $-1,53 \%$ \\
\hline 2.07 Kreatywność & $76,54 \%$ & $70,33 \%$ & $6,21 \%$ \\
\hline 2.08 Zorientowanie na wyniki & $86,11 \%$ & $94,51 \%$ & $-8,40 \%$ \\
\hline 2.12 Konflikty i kryzysy & $45,38 \%$ & $57,97 \%$ & $-12,59 \%$ \\
\hline 2.13 Wiarygodność & $90,74 \%$ & $90,66 \%$ & $0,08 \%$ \\
\hline 2.14 Docenianie wartości & $81,48 \%$ & $80,77 \%$ & $0,71 \%$ \\
\hline 2.15 Etyka & $91,67 \%$ & $90,11 \%$ & $1,56 \%$ \\
\hline Obszar kompetencji kontekstowych & $57,47 \%$ & $55,05 \%$ & $2,41 \%$ \\
\hline 3.01 Orientacja na projekty & $53,01 \%$ & $48,08 \%$ & $4,93 \%$ \\
\hline 3.05 Stałe struktury organizacji & $53,71 \%$ & $51,19 \%$ & $2,52 \%$ \\
\hline 3.08 Zarządzanie zasobami ludzkimi & $65,55 \%$ & $65,27 \%$ & $0,28 \%$ \\
\hline
\end{tabular}

Źródto: opracowanie wtasne

Tabela 9. Porównanie wyników ogólnych egzaminu dla studentów uniwersytetów i uczelni technicznych - analiza wariancji (ANOVA)

\begin{tabular}{|c|c|c|c|c|c|c|c|}
\hline \multicolumn{3}{|c|}{ PODSUMOWANIE } & & & & & \\
\hline \multicolumn{2}{|c|}{ Grupy } & $\begin{array}{l}\text { Liczba } \\
\text { egzaminów }\end{array}$ & $\begin{array}{c}\text { Suma } \\
\text { uzyskanych } \\
\text { punktów }\end{array}$ & $\begin{array}{l}\text { Średnia } \\
\text { punktów }\end{array}$ & $\begin{array}{l}\text { Wariancja } \\
\text { punktów }\end{array}$ & & \\
\hline \multicolumn{2}{|c|}{$\begin{array}{l}\text { Kierunki Ekonomiczne } \\
\text { i Zarządzania }\end{array}$} & 230 & 14010 & 60,91304 & 73,04917 & & \\
\hline \multicolumn{2}{|c|}{ Kierunki Techniczne } & 63 & 3868 & 60,4375 & 87,32937 & & \\
\hline \multicolumn{3}{|c|}{ ANOVA } & & & & & \\
\hline $\begin{array}{c}\text { Źródło } \\
\text { wariancji }\end{array}$ & \multicolumn{2}{|c|}{ SS } & df & MS & $\mathrm{F}$ & Wartość-p & Test F \\
\hline $\begin{array}{l}\text { Pomiędzy } \\
\text { grupami }\end{array}$ & \multicolumn{2}{|c|}{11,32246} & 1 & 11,32246 & 0,148725 & 0,700038 & 3,873502 \\
\hline $\begin{array}{l}\text { W obrębie } \\
\text { grup }\end{array}$ & \multicolumn{2}{|c|}{22230,01} & 292 & 76,13017 & & & \\
\hline Razem & \multicolumn{2}{|c|}{22241,33} & 293 & & & & \\
\hline
\end{tabular}

Źródło: opracowanie własne 


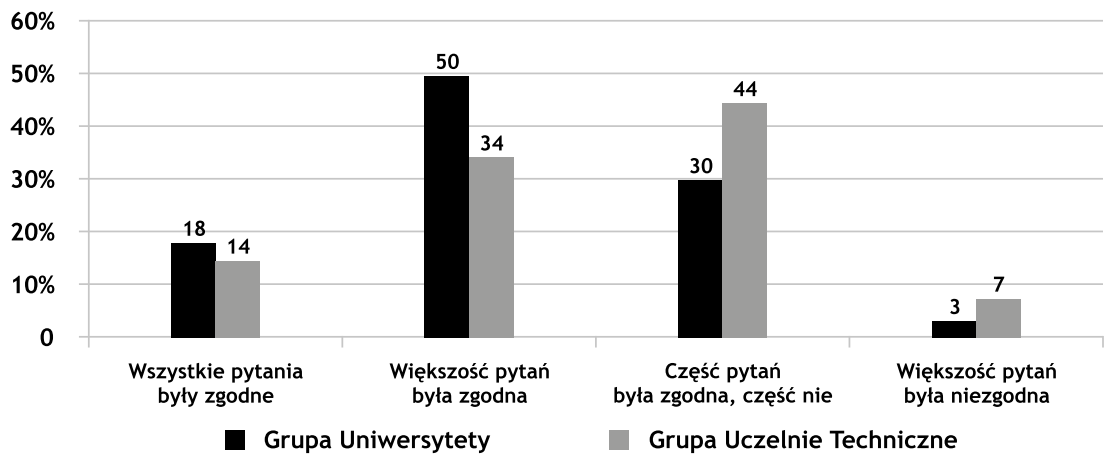

Rys. 2. Zgodność tematyki pytań egzaminacyjnych z programami zajęć na Wydziale Źródto: opracowanie wtasne

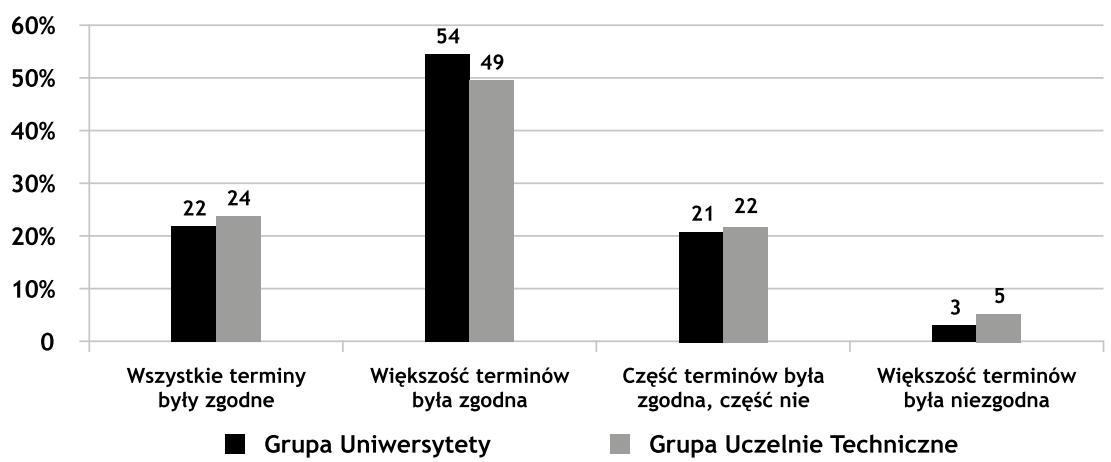

Rys. 3. Zgodność terminologii stosowanej na egzaminie z używaną na zajęciach na Wydziale

Źródło: opracowanie wtasne

nieco niższe w obszarze kompetencji technicznych, a najsłabsze w kompetencjach kontekstowych,

- wszystkie elementy kompetencji behawioralnych rozwinięte są na wysokim poziomie powyżej 50\% (próg zaliczenia egzaminu IPMA-Student),

- wyniki w zakresie poszczególnych kompetencji technicznych różnią się znaczniej, najlepiej rozwiniętym elementem jest komunikacja, najsłabiej ryzyko, zakres projektu oraz czas (wynik poniżej 50\%),

- najsłabiej rozwiniętym elementem kompetencji kontekstowych jest zrozumienie orientacji na projekty,

- wyniki egzaminów studentów kształcących się na uczelniach typu uniwersytety i uczelnie techniczne nie różnią się w sposób statystycznie istotny,

- wyniki egzaminów certyfikacyjnych studentów w rozróżnieniu na kierunki ekonomiczno-zarządcze i techniczne nie wykazują istotnych różnic,

- istnieje przestrzeń do doskonalenia kształcenia studentów w zakresie pracy nad jednolitym słownictwem zarządzania projektami i uzupełnienia treści przedmiotów tak, aby studenci nie dostrzegali luk pomiędzy realizowanymi programami kształcenia a zakresem opracowanego wspólnie $\mathrm{z}$ biznesem modelu IPMA-Student.

Badania wykonano na próbie 291 osób. Analizowano wyniki rzeczywistych egzaminów, co może oznaczać wyższy poziom obiektywizmu analizowanych danych niż samoceny, możliwej do uzyskania na podstawie np. badania ankietowego. Autorzy planują kontynuowanie badań w kolejnych okresach w celu uzyskania informacji, czy wyniki różnią się od siebie w czasie.

\section{dr Joanna Rzempała Uniwersytet Szczeciński Wydziat Zarządzania i Ekonomiki Usług ORCID: 0000-0002-0542-9370 e-mail: joanna.rzempala@wzieu.pl}

\section{dr inż. Tomasz Wiśniewski Uniwersytet Szczeciński Wydział Zarządzania i Ekonomiki Usług ORCID: 0000-0002-6308-8447 e-mail: tomasz.wisniewski@wzieu.pl}

\section{Przypisy}

1) Certyfikacja IPMA-Student obejmuje większą część kompetencji uwzględnionych w certyfikacji biznesowej IPMA, zakres kompetencji został wypracowany poprzez współpracę środowiska akademickiego oraz biznesowego. Certyfikat IPMA-Student potwierdza kwalifikacje i umiejętności wymagane przez rynek pracy dla członków zespołów projektowych.

2) Podstawą akredytacji jest przygotowanie tzw. macierzy kompetencji wraz z kartami przedmiotów wchodzącymi w skład akredytowanych zajęć. W macierzy przedstawione są powiązania efektów kształcenia IPMA-Student (ISEK) z przedmiotowymi efektami kształcenia uczelni (PEK). Wymagana liczba godzin dydaktycznych realizowanych $\mathrm{z}$ uczestnictwem nauczyciela akademickiego to dla studiów stacjonarnych 60 godzin, dla studiów niestacjonarnych 30 godzin. Oznacza to, 
Tabela 10. Porównanie wyników egzaminów w poszczególnych obszarach kompetencji z perspektywy profilu studiów

\begin{tabular}{|c|c|c|c|}
\hline & $\begin{array}{c}\text { Studia ekonomiczne/ } \\
\text { zarządzanie }\end{array}$ & Studia techniczne & Różnica \\
\hline Obszar kompetencji technicznych & $58,85 \%$ & $58,57 \%$ & $0,28 \%$ \\
\hline 1.01 Sukces zarządzania projektem & $74,52 \%$ & $67,10 \%$ & $7,41 \%$ \\
\hline 1.02 Interesariusze & $64,52 \%$ & $72,37 \%$ & $-7,85 \%$ \\
\hline 1.03 Wymagania i cele projektu & $66,94 \%$ & $70,18 \%$ & $-3,24 \%$ \\
\hline 1.04 Ryzyko: zagrożenia i szanse & $37,37 \%$ & $32,89 \%$ & $4,47 \%$ \\
\hline 1.05 Jakość & $52,82 \%$ & $42,77 \%$ & $10,06 \%$ \\
\hline 1.06 Organizacja projektu & $64,84 \%$ & $67,54 \%$ & $-2,70 \%$ \\
\hline 1.07 Praca zespołowa & $56,13 \%$ & $57,11 \%$ & $-0,98 \%$ \\
\hline 1.08 Rozwiązywanie problemów & $62,91 \%$ & $85,31 \%$ & $-22,40 \%$ \\
\hline 1.09 Struktury projektu & $50,00 \%$ & $53,07 \%$ & $-3,07 \%$ \\
\hline 1.10 Zakres i produkty cząstkowe & $54,52 \%$ & $46,41 \%$ & $8,11 \%$ \\
\hline 1.11 Czas i etapy (fazy) projektu & $42,90 \%$ & $45,79 \%$ & $-2,89 \%$ \\
\hline 1.12 Zasoby & $65,59 \%$ & $63,45 \%$ & $2,14 \%$ \\
\hline 1.13 Koszty i zasoby finansowe & $67,97 \%$ & $67,54 \%$ & $0,43 \%$ \\
\hline 1.15 Zmiany & $61,29 \%$ & $60,09 \%$ & $1,20 \%$ \\
\hline 1.16 Kontrola i raporty & $72,90 \%$ & $70,79 \%$ & $2,11 \%$ \\
\hline 1.18 Komunikacja & $82,80 \%$ & $83,48 \%$ & $-0,68 \%$ \\
\hline Obszar kompetencji behawioralnych & $74,73 \%$ & $76,52 \%$ & $-1,79 \%$ \\
\hline 2.01 Przywództwo & $58,60 \%$ & $57,75 \%$ & $0,85 \%$ \\
\hline 2.02 Zaangażowanie i motywacja & $100,00 \%$ & $97,15 \%$ & $2,85 \%$ \\
\hline 2.04 Asertywność & $95,16 \%$ & $94,30 \%$ & $0,86 \%$ \\
\hline 2.07 Kreatywność & $60,22 \%$ & $76,02 \%$ & $-15,81 \%$ \\
\hline 2.08 Zorientowanie na wyniki & $95,16 \%$ & $90,35 \%$ & $4,81 \%$ \\
\hline 2.12 Konflikty i kryzysy & $58,07 \%$ & $51,98 \%$ & $6,09 \%$ \\
\hline 2.13 Wiarygodność & $95,16 \%$ & $89,47 \%$ & $5,69 \%$ \\
\hline 2.14 Docenianie wartości & $80,65 \%$ & $81,14 \%$ & $-0,49 \%$ \\
\hline 2.15 Etyka & $82,26 \%$ & $92,98 \%$ & $-10,72 \%$ \\
\hline Obszar kompetencji kontekstowych & $53,55 \%$ & $56,61 \%$ & $-3,06 \%$ \\
\hline 3.01 Orientacja na projekty & $45,57 \%$ & $51,10 \%$ & $-5,53 \%$ \\
\hline 3.05 Stałe struktury organizacji & $50,54 \%$ & $52,56 \%$ & $-2,03 \%$ \\
\hline 3.08 Zarządzanie zasobami ludzkimi & $63,55 \%$ & $65,88 \%$ & $-2,33 \%$ \\
\hline
\end{tabular}

Źródto: opracowanie wtasne

że programy kształcenia akredytowanych uczelni zawierają treści związane $\mathrm{z}$ kształceniem $\mathrm{w}$ obszarze zarządzania projektami na poziomie umożliwiającym studentom zdobycie kompetencji zarządzania projektami.

3) Warto podkreślić, iż model IPMA-Student kładzie największy nacisk na kompetencje techniczne zarządzania projektami. Kompetencje techniczne obejmują 70\% wszystkich elementów kompetencji, behawioralne i kontekstowe po $15 \%$. Struktura egzaminu jest odzwierciedleniem struktury modelu IS.

\section{Bibliografia}

[1] Al-Emranab A., Elsherifa H.M., Shaalanac K. (2016), Investigating Attitudes towards the Use of Mobile Learning in Higher Education, „Computers in Human Behavior”, Vol. 56, pp. 93-102.
[2] Bakker R.M. (2010), Taking Stock of Temporary Organizational Forms: A Systematic Review and Research Agenda, „International Journal of Management Reviews", Vol. 12, No. 4, pp. 466-486.

[3] Dainty A., Cheng M., Moore D. (2005), A Comparison of the Behavioural Competencies of Client-focused and Production-focused Project Managers in the Construction Sector, „Project Management Journal”, Vol. 36, No. 2, pp. 39-48.

[4] Dałkowski B., Staśto L., Zalewski M. (2009), Nationale Competence Baseline, Polskie Wytyczne Kompetencji IPMA, v.3,0, Stowarzyszenie Project Management Polska.

[5] Dulewicz V., Higgs M.J. (2005), Assessing Leadership Dimensions, Styles and Organizational Context, "Journal of Managerial Psychology", Vol. 20, No. 2, pp. 105-23.

[6] Gemünden H.G., Schoper Y. (2014), First Results of the New Expert Survey 2014: Future Trends, „Projekt Management Aktuell”, Vol. 25, No. 5, pp. 6-16. 
[7] https://www.ipma.pl/sites/default/files/certyfikacja/NCB v3_PL.pdf, data dostępu: 10.04 .2019 r.

[8] Keegan A., Den Hertogg D. (2004), Transformational Leadership in a Projectbased Environment, „International Journal of Project Management”, Vol. 22, No. 8, pp. 609-617.

[9] Łapuńka I., Pisz I. (2016), Potrzeby rynku pracy siła napędowa rozwoju kompetencji $w$ zakresie zarzadzania projektami, „Przedsiębiorczość i Zarządzanie”, Tom XVII, Zeszyt 2, Część II, s. 141-154.

[10] Manpower (2018), Niedobór talentów, https://www. manpowergroup.pl/wp-content/uploads/2018/08/NiedoborTalentow_2018_Polska.pdf, data dostępu: 17.02.2019 r.

[11] PARP (2016), Bilans Kapitału Ludzkiego, https:// www. parp.pl, data dostępu: 14.02.2019 r.

[12] Standish Group (2015), CHAOS Report 2015, https://www. infoq.com/articles/standish-chaos-2015, access date: 17.02.2019.

[13] Thomas J., Mengel T. (2008), Preparing Project Managers to Deal with Complexity - Advanced Project Management Education, „International Journal of Project Management”, Vol. 26, pp. 304-315.

[14] Trocki M., Bukłaha E. (2015), Programy nauczania w szkołach wyższych, a obecne i przyszłe trendy w zarzadzaniu projektami, Konferencja Seminarium PM Edukacja, Szkoła Główna Handlowa w Warszawie (materiał niepublikowany).

[15] Turner R., Huemann M., Anbari F., Bredillet C. (2010), Perspectives on Projects, Routledge, London, New York.

[16] Wirkus M., Tubielewicz K. (2018), Kluczowe czynniki sukcesu projektu i przedsiębiorstwa w sieci tymczasowej, „Przedsiębiorstwo we Współczesnej Gospodarce - Teoria i Praktyka", Nr 3, s. 75-87.

[17] Winter M., Smith C., Morris P., Cicmil S. (2006), Directions for Future Research in Project Management: The Main Findings of a UK Government Funded Research Network, „International Journal of Project Management”, Vol. 24, pp. 638-649.

\section{Student Competence Level in the Field of Project Management at Universities and Technical Universities. The Case of the IPMA-Student Programme}

\section{Summary}

Training in project management is an important field for both universities and educators, as well as employers looking for qualified workers in the labour market. Project managers play an important role in many sectors of industry and the public sector as well. The aim of the article is to present the educational results and the level of student competences in the area of project management at Polish universities cooperating within the IPMA-Student Programme. The programme has been implemented in Poland for 5 years, and the number of collaborating universities and students interested in certification is constantly growing. The authors have attempted to examine the difference in the results of certification exams depending on the type of university and the field of study in particular elements of project management competence. On the basis of the research conducted, it can be concluded that there is no significant difference in the percentage of correct answers given during the certification examination among partner universities. Students of all groups obtain the highest ratings in terms of behavioural competences, and the weakest in terms of contextual competences. At the same time, individual areas and elements of project management competence are similarly developed, both in terms of the type of university (economic and technical) and the field of study.

\section{Keywords}

project management competence, project management, academic education, student competence, student education, student education, competence certification 